Е. А. Гаричева

Великий Новгород

DOI: 10.15393/j9.art.2011.317

\section{ПРЕОБРАЖЕНИЕ ЛИЧНОСТИ В РОМАНЕ Ф. М. ДОСТОЕВСКОГО «ПОДРОСТОК»}

及 черновике к роману «Подросток» есть запись:

Да ты образи себя прежде, да и каждое дело свое ${ }^{1}$.

По замыслу Достоевского, главный герой должен испытать состояние духовного преображения:

Молодой человек (великий грешник) после ряда прогрессивных падений вдруг становится духом, волей, светом и сознанием на высочайшую из высот (XVI, 7).

В окончательном варианте романа Аркадий Долгорукий признается:

Кончив же записки и дописав последнюю строчку, я вдруг почувствовал, что перевоспитал себя самого, именно процессом припоминания и записывания (XIII, 447).

Категория религиозного преображения личности определяет жанровую природу и хронотоп романа «Подросток». В работе «Формы времени и хронотопа в романе» М. Бахтин отметил, что преображение человека показано в жанре кризисного жития, которое выделяется из агиографической литературы тем, что в нем дается два или три образа героя:

(C) Гаричева Е. А., 2011

* Работа выполнена при поддержке Российского гуманитарного научного фонда (проект 08-04-46402a/3).

${ }^{1}$ Достоевский Ф. М. Полн. собр. соч.: В 30 т. Л.: Наука, 1972-1980. T. 16. С. 178. Далее цитируем по этому изданию с указанием в скобках тома - римской и страниц - арабскими цифрами.
В раннехристианских кризисных житиях... дается обычно только два образа человека, разделенных и соединенных кризисом и перерождением, - образ грешника (до перерождения) и образ праведника - святого (после кризиса и перерождения). Иногда даются и три образа, именно в тех случаях, когда особо выделен и разработан отрезок жизни, посвященный очистительному страданию, аскезе, борьбе с собой... ${ }^{2}$

В романе «Подросток» Аркадий слышит от Макара Долгорукого одно из таких житий:

Я запомнил, например, из этих рассказов один длинный рассказ - «Житие Марии Египетской»... Я прямо говорю: это почти нельзя было вынести без слез, и не от умиления, а от какого-то странного восторга: чувствовалось что-то необычайное и горячее, как та раскаленная песчаная степь со львами, в которой скиталась святая (XIII, 309).

В черновике к роману Достоевский делает запись, ставя рядом «золотой век» и идею религиозного преображения личности: 420).

Золотой век. Макар Иванович и Мария Египетская (XVI,

Другая запись говорит о том, что с Макаром Долгоруким, который влияет на Аркадия, происходит преображение:

В этих существах, как в Макаре, - Царствие Божие (XVI, 399).

«Подросток» продолжает проблематику романа «Преступление и наказание», Аркадий Долгорукий вбирает в себя черты Раскольникова и Аркадия Свидригайлова. Как Раскольников и Свидригайлов, он приезжает в Петербург из Центральной России. Подобно этим героям, он жил в деревне и несет в себе воспоминание об идиллии (XIII, 92). Имя Аркадий соотносится со словом «идиллия»: фрразеологизм «Аркадская идиллия» означает «счастливая страна, беззаботная жизнь» ${ }^{3}$. Именно там, в деревенской церкви, Аркадий испытал одно из самых сильных чувств во время причащения, которое у него связано с первым воспоминанием о матери и Церкви:

\footnotetext{
2 Бахтин М. М. Эпос и роман. СПб., 2000. С. 43.

${ }^{3}$ Ашукин Н. С., Ашукина М. Г. Крылатые слова. Литературные цитаты. Образные выражения / Отв. ред. В. П. Вомперский. М., 1986. С. 29.
} 
...Вас, мама, помню ясно только в одном мгновении, когда меня в тамошней церкви раз причащали и вы приподняли меня принять дары и поцеловать чашу; это летом было, и голубь пролетел насквозь через купол, из окна в окно... (XIII, 92).

Аркадий Долгорукий, как и Раскольников, является носителем идеи, смысл которой - «уединенное и спокойное сознание силы» (XIII, 74). Он тоже не без великодушия:

Я отдам все мои миллионы людям, пусть общество распределит там все мое богатство, а я - я вновь смешаюсь с ничтожеством! (XIII, 76).

Подобно главному герою «Преступления и наказания», Аркадий делает «пробу» (XIII, 39) и выбирает «уединение». Его комната напоминает «гроб», как и комната Раскольникова (XIII, 101). Связывают его с людьми, даже в момент кризиса, мать и сестра (XIII, 62).

Но, в отличие от Свидригайлова, художественное пространство Аркадия Долгорукого в романе расширяется. Кроме того, динамика внутреннего движения героев прямо противополжна, эту разновекторность можно увидеть, анализируя представленную в произведениях топографию Петербурга. Если Свидригайлов в финале оказывается на Петербургской стороне Северной столицы, где и кончает жизнь самоубийством, то Подросток начинает движение по Петербургу в начале романа с Петербургской стороны, где живет его товарищ по гимназии Зверев (XIII, 112). Здесь у Дергачева собираются нигилисты, которые говорят о возможном близком конце России. Здесь Подросток задумывается о «петербургском типе», который показан у Пушкина в образе Германна из «Пиковой дамы» (XIII, 113). И здесь Аркадия посещают мысли о конце света:

А что, и весь этот гнилой, склизлый город, подымется с туманом и исчезнет как дым, а останется прежнее финское болото, а посреди его, пожалуй, для красы бронзовый всадник на жарко дышащем, загнанном коне (XIII, 113).

\section{Н. А. Синдаловский утверждает:}

В 19 веке были живы легенды о том, что Фальконе вложил в композицию монумента «тайную мысль, что когда-нибудь императорской России придется низвергнуться в бездну с высоты своей безрассудной скачки» ${ }^{4}$.

Также исследователь вспоминает о том, что в среде раскольников родилась легенда о Медном всаднике как всаднике из Апокалипсиса ${ }^{5}$.

Носителем апокалипсической идеи в романе «Подросток» становится Версилов, который пережил закат Европы, видел «заходящее солнце последнего дня европейского человечества» (XIII, 375). Старый князь Сокольский сообщает, что в то время он «пугал» Страшным судом (XIII, 45).

Решение «уйти в идею» Аркадий принимает в первый день пребывания в Петербурге - 19 августа. Это день памяти Андрея Стратилата, возможно, небесного покровителя Андрея Петровича Версилова. В черновиках Достоевский проводит параллель между идеей Аркадия и идеей Версилова: это «нечистый идеал», основанный на «самообожании» (XVI, 239). Однако из дома Аркадий уходит 21 сентября, в день отдания праздника Воздвижения Честного и Животворящего Креста Господня. Оказавшись у Васина на Фонтанке, Аркадий отмечает:

Так как, кроме того, был какой-то праздник, то я и предполагал, что застану его наверное (XIII, 116).

Свое решение уйти из дома он обосновывает Библией, вспоминая притчу о блудном сыне:

Когда требует совесть и честь, и родной сын уходит из дому. Это еще в Библии (XIII, 131).

Но вскоре Аркадий признается, что для него Версилов это также «блудный сын»:

Был мертв и ожил, пропадал и нашелся (XIII, 152).

Путь Аркадия в романе - это путь русского человека вообще, который, видимо, сравнивается Достоевским с крестом.

На наш взгляд, Достоевский в романе «Подросток» продолжает не только традиции кризисного жития, но и хожения (или хождения). Паломник идет крестным путем

\footnotetext{
${ }^{4}$ Синдаловский Н. А. Призраки Северной столицы. Легенды и мифь питерского зазеркалья. М., 2006. С. 216.

5 Там же. С. 215
} 
Христа, желая стяжать Дух Святый. Один из источников текста Достоевский указывает в черновиках:

Макар Иванов рассказывает о вечерях и стояниях, взять из Пардения (XVI, 150).

«Сказание о странствии и путешествии по России, Молдавии, Турции и Св. Земле постриженика Св. Горы Афонской инока Парфения» принадлежит к жанру хождения (XII, 234). Кроме того, первоначально писатель останавливается на жанре романа-путешествия, который исторически связан с хождением: в черновике московский «мечтатель» знакомится с русской действительностью на станциях Николаевской железной дороги: Малая Вишера, Любань, Петербург (XVI, 60).

Любопытно, что на станции Малая Вишера Аркадию Свидригайлову является призрак покойной жены Марфы Петровны, и он решает отказаться от идеи жениться на Дунечке. Возможно, новгородская топонимика в произведениях Достоевского объясняется тем, что во время путешествия по железной дороге писатель мог видеть, как на маловишерском погосте в 1861-1864 годах строился храм во имя Чудотворца Николая 6 . Видимо, звук колоколов кладбищенской церкви, которая находилась рядом с железной дорогой, становится особым знаком для героя.

В романах «Преступление и наказание» и «Подросток» пространство и время сакрализуются. Большое внимание уделяется почитанию св. Николая Чудотворца: Раскольников в день Явления Казанской Божией Матери после пророческого сна возвращается по Николаевскому мосту, проходит мимо часовни св. Николая. Переломным моментом для героя становится известие о решении его земляка Николая пострадать и страданием очиститься.

В романе «Подросток» Версилов рассказывает о «золотом веке» человечества в День памяти св. Николая, 6 декабря. Аркадий с радостью принимает Версилова и его идею. В своих записках Аркадий замечает 3 декабря, что день рождения Софьи Андреевны будет через пять дней (XIII, $307,329)$. Затем пишет, что Макар Иванович не дожил до дня рождения Софьи Андреевны три дня (XIII, 393).

${ }^{6}$ ГИАНО, фр-480, 3309, л. 16.
В романе Достоевского «Подросток» Аркадий проходит два круга испытаний. Начало первого круга испытаний совпадает с началом Рождественского поста (15 ноября), что было отмечено В. Н. Захаровым 7 . Сам Аркадий оценивает все происшедшее с ним в посту как искушение (XIII, 225), испытание его идеала (XIII, 242). В первом круге он проверяется свободой, причем это испытание вводится в контекст общего настоящего России:

Кто не мыслит о настоящей минуте России, тот не гражданин! Я смотрю на Россию, может быть, с странной точки: мь пережили татарское нашествие, потом двухвековое рабство и уж конечно потому, что то и другое нам пришлось по вкусу. Теперь дана свобода, и надо свободу перенести: сумеем ли? (XIII, 194-195).

Решающую роль в самоопределении героя играют его мать Софья Андреевна и странник Макар Иванович Долгорукий. В момент кризиса, когда Аркадий готов стать поджигателем, он вспоминает мать и ее молитву к Пречистой Богородице и Николаю Чудотворцу (XIII, 272). Приходя в сознание после болезни, Подросток видит косые лучи красного заходящего солнца (сквозной символ Достоевского, связанный с ситуацией преображения) и слышит Иисусову молитву, которую творит Макар Иванович (XIII, 283).

«Катастрофра» приходится, по нашим подсчетам, на 17 ноября: Сокольский-младший предлагает Аркадию отправиться на рулетку с деньгами, которые он выиграл «третьего дня» - 15 ноября (XIII, 240). После позора на рулетке, в «адскую ночь», Аркадий вновь оказывается на Дворцовой площади Петербурга, рядом с Медным всадником, и жаждет поджечь город, который создавался Петром Первым как новый Рим. В черновиках к роману «Подросток» есть запись:

Bce поджечь. Ночь на улицах, темный лик Богородицы у Знамения (XVI, 62).

От окончательного падения Подростка спасает молитва матери. Аркадий с покаянием вспоминает, как сразу после

\footnotetext{
7 Захаров В. Н. Символика христианского календаря в произведениях Достоевского // Новые аспекты в изучении Достоевского: Сб. науч. тр. Петрозаводск, 1994. С. 46
} 
Святой недели в Москве Софья Андреевна благословляет его с молитвой:

...Ну, Господь с тобой... ну, храни тебя ангелы небесные, Пречестная Мать, Николай-У годник (XIII, 272).

Приходит в сознание после «катастрофы» и болезни Подросток 27 ноября. Это день Явления чуда от иконы Знамения: Аркадий возвращается домой от Ламберта 18 ноября, после чего наступают «девять дней беспамятства» (XIII, 280). Память о чудесном избавлении Новгорода от суздальцев в XII веке благодаря заступничеству Пресвятой Богородицы через Ее образ Знамение генетически живет в русском человеке. Вероятно, поэтому в черновике к роману «Подросток» Достоевский замечает по поводу отца Аркадия, Версилова:

...от суздальских князей двенадцатого столетия (XVI, 415).

Встреча Аркадия с Макаром Долгоруким происходит 30 ноября - в день Андрея Первозванного, установившего на Руси, близ Новгорода, крест:

На четвертый день моего сознания я лежал, в третьем часу пополудни, на моей постели, и никого со мной не было. День был ясный, и я знал, что в четвертом часу, когда солнце будет закатываться, то косой красный луч его ударит прямо в угол моей стены и ярким пятном осветит это место... Я судорожно повернулся всем телом и вдруг, среди глубокой тишины, ясно услышал слова: «Господи, Иисусе Христе, Боже Наш, помилуй нас». Слова произнеслись полушепотом, за ними следовал глубокий вздох всею грудью, а затем все опять совершенно стихло (XIII, 283-284).

Макар Долгорукий своей жизнью утверждает нестяжательство, о котором писал Иоанн Лествичник:

Нестяжание есть отложение земных попечений, беззаботность о жизни, невозбраняемое путешествие, вера заповедям Спасителя; оно чуждо печали ${ }^{8}$.

Как известно, этот принцип особенно отстаивал Нил Сорский. В Записной тетради 1875-1876 годов Достоевский делает заметку: «О святом Ниле Сорском и о собственно-

8 Лествица, возводящая на небо преподобного отца нашего Иоанна, игумена Синайской горы. М., 1997. С. 260. сти» (XXIV, 157). В рукописных редакциях к «Подростку» Достоевский также вспоминает Нила Сорского:

А кто не хочет трудиться, пусть тот и не ест, - сказано прежде (Нил Сорский) (XVI, 143).

Эти слова взяты писателем из Предания Нила Сорского в редакции Уварова и связаны с практикой делания «умной молитвы», безмолвия:

И Павел апостол повелевает в безмолвии делающим свой хлеб ясти и запретительнейшее глаголет: Аще кто не хочет делати, да не аст ${ }^{9}$.

Формой нестяжания является странничество. И. Лествичник объясняет это тем, что сам Христос был странником:

Никто в такой мере не предал себя странничеству, как Тот Великий, Который услышал... изыди от земли твоея, и от рода твоего, и от дому отца твоего (Быт. 12:1) ${ }^{10}$.

Макар Долгорукий вел страннический образ жизни и в странничестве обрел благодать.

Макар Иванович, как и Нил Сорский, мечтает о пустыни и проповедует нестяжание:

То ли у Христа: «Поди и раздай твое богатство и стань всем слуга». И станешь богат паче прежде в бессчетно раз; ибо не пищею только, не платьями ценными, не гордостью и не завистью счастлив будешь, а умножившеюся бессчетно любовью (XIII, 311).

Нестяжание даст, по Макару Ивановичу, и премудрость:

Тогда и премудрость приобретешь не из единых книг токмо, а будешь с самим Богом лицом к лицу... (XIII, 311).

Сам Макар Долгорукий отличается прозорливостью:

Было у меня сегодня, после утренней молитвы, такое в сердце чувство, что уж более отсюда не выйду; сказано было (XIII, 330).

Версилову Долгорукий предсказывает возрождение:

...Бог и без меня ваше сердце найдет (XIII, 330).

${ }^{9}$ Нил Сорский. Предание и Устав / Вступ. ст. М. С. БоровковойМайковой. СПб., 1912. С. V.

10 Лествица, возводящая на небо преподобного отца нашего Иоанна, игумена Синайской горы. С. 56. 
Одним из прототипов Макара Долгорукого многие считают святителя Тихона Задонского ${ }^{11}$. Достоевский в письме к Майкову, излагая план «Жития великого грешника», признавался:

...Хочу выставить во второй повести главной фигурой Тихона Задонского, конечно, под другим именем... Не говорите же про Тихона. Авось, выведу величавую, положительную, святую фигуру. Это уж не Констанжогло-с и не немец (забыл фамилию) в Обломове. Почем мы знаем: может быть, именно Тихон и составляет наш русский положительный тип, который ищет наша литература, а не Лавровский, не Чичиков, не Рахметов и пр. Правда, я ничего не создам, я только выставлю действительного Тихона, которого я принял в свое сердце давно с восторгом, но я сочту, если удастся, и әто для себя уже важным подвигом (XXIX(1), 118).

Путь Макара Ивановича напоминает путь героя кризисного жития. Образ грешного Макара Долгорукого создается в начале записок Аркадия: «он был тогда мрачен», «был характера упрямого, подчас даже рискованного; говорил с амбицией, судил бесповоротно»; «уважение он приобрел всеобщее, но, говорят, был всем несносен» (XIII, 8-9). Иного Макара Ивановича Подросток видит после кризиса, который с ним произошел: «светлый, веселый» смех, «очень голубые лучистые глаза» (XIII, 285) и общее ощущение «благообразия» (XIII, 291).

О том, что Макар Иванович полностью от греховной тварной природы не освободился, свидетельсвует эпизод, когда он обращается с напоминанием о прошлом к Версилову и Софье Андреевне:

А виновен в сем деле Богу / всех больше я; // ибо хоть и господин мой были, / но все же не должен был я слабости сей попустить. /// Посему и ты, / Софья, / не смущай свою душу слишком, / ибо весь твой грех - / мой, // а в тебе, / как мыслю, / и разуменье-то вряд ли было, / а пожалуй, / и в вас тоже, / сударь, / вкупе с нею, - // улыбнулся он с задрожавшими от какой-то боли губами, - // и хоть мог бы я тогда поучить тебя, / супруга моя, / даже жезлом, / да и должен

${ }^{11}$ Якубович И. Д. К характеристике стилизации в «Подростке» // Достоевский. Материалы и исследования. Л., 1978. С. 136-143. был, - / но жақарко стало, / как предо мной упала в слезах / и ничего не потаила... /// Ноги мои целовала /// (XIII, 331).

В этот момент чувства, оскорбленные и подавленные, проявляются в смене интонаций его голоса: по мере движения высказывания вперед в речи героя все больше проявляются волевые, жесткие интонации, от покаяния герой переходит к укору, а затем в его словах звучат и угрозаустрашение и даже самоутверждение («ноги мои целовала»). Расширению звуковой волны препятствует обилие согласных звуков в речи героя, причем в определенный момент аллитерационное давление усугубляется («жезлом» - «должен» - «жалко»). В это время место любви к ближнему в душе Макара занимает печаль о себе, и голос героя свидетельствует об этом.

Прежний Макар Долгорукий проявляет себя только однажды, в настоящем же мы видим героя смиренного и кроткого. Меняя, смягчая свою природу, Макар вступает на лествицу духовную и получает дар благодати, который чувствует в нем Подросток.

Для преп. Нила Сорского нестяжание - это борьба с грехами, очищение сердца и восхождение по лествице духовной. Главным средством борьбы с прилогами (греховными помыслами) Нил Сорский полагает Иисусову молитву. В своем «Предании» Нил Сорский пишет о Фаворском свете, который можно обрести благодаря духовному деланию:

Зрю свет, его же мир не имать, посреди келия на одре сидя, внутрь себе зрю Творца миру ${ }^{12}$

Особое внимание Нил Сорский уделяет благодатным слезам:

Егда же вниманием, сиречь хранением сердечным, от Божественной благодати действо духовное в молитве явится, теплоту влагающе согревающую сердце и утешающую душу, и к любви Божии и человечестве неизреченне распаляющи, и ум веселящи, и сладость от внутренних и радование попадающи, тогда слезы самоисходне проливаются и ненужне от себе истачаются, утешающи болезненую душу, подобно младенцу в себе плачуще...13

${ }^{12}$ Нил Сорский. Предание и Устав. С. 28-29.

13 Там же. С. 77. 
Обретение благодатных слез у Нила Сорского сравнивается с рождением младенца в душе человека.

Великий грешник, совершивший убийство «одного из малых сих», купец Скотобойников, герой рассказа Макара Ивановича, получает совет предать себя воле Божией и приносит в жертву все свое имущество:

Был я тверд и жесток, и тягости налагал, но мню, что за скорби и странствия предстоящие не оставит без воздаяния Господь, ибо оставить все сие есть немалый крест и немалая скорбь (XIII, 322).

В финале рассказа он обретает дар благодатных слез:

И получил дар слезный: кто бы с ним ни заговорил, так и зальется слезами (XIII, 321).

Так, Макар Долгорукий, как духовный отец Подростка, противопоставляет идею свободы, основанной на своеволии, идее нестяжания по Нилу Сорскому и Иоанну Лествичнику.

Во втором круге испытаний в сердце Аркадия происходит борьба между «жаждой благообразия», которую он испытал, общаясь с Макаром Ивановичем, и страстной, «хищной» натурой, унаследованной от Версилова:

Непомерная жажда этой жизни, $u x$ жизнь захватила весь мой дух и... и еще какая-то другая сладостная жажда, которую я ощущал до счастья и мучительной боли (XIII, 297).

Ему снится пророческий сон. Он видит сцену с Ахмаковой (она произойдет в финале романа, но на его месте будут Ламберт и Версилов - «двойники» героя) и чувствует в себе "душу паука" и "развратное сердце» (XIII, 306). Затем сон с пауками видит младший князь Сокольский, который также оказывается «двойником» героя (XIII, 335).

Подобная борьба происходит в душе Версилова. После смерти Макара Ивановича он раскрывает Аркадию свою идею - идею русского человека как «высшего культурного типа", в котором "всемирное боление за всех» (XIII, 376). Версилов говорит Аркадию о «заходящем солнце последнего дня европейского человечества» (XIII, 375). В черновиках Достоевский вкладывает в его уста мысль о европейском социализме как торжестве «антихриста»:
Социализм состоит в том, чтоб, выйдя из-под христианской цивилизации и для того разрушив ее, создать свою на основании отрицания Небесного Царства и ограничиваясь одним земным. Прямо антихрист (XVI, 109)

От боли за себя Версилов переходит к боли за всех, и именно на этих страницах романа Достоевский вкладывает в уста героя свои сокровенные мысли о «золотом веке» человечества и о «всепримирении идей» как «высшей русской мысли». Картина «царства Божия» на земле завершается видением Христа, а в описании будущих людей слышатся страстные ноты голоса самого автора:

O, они торопились бы любить, чтоб затушить великую грусть в своих сердцах. Они были бы горды и смелы за себя, но сделались бы робкими друг за друга; каждый трепетал бы за жизнь и за счастие каждого (XIII, 379).

Здесь Версилов творит свою речь в жанре, близком к акафисту: умиление и восторг звучат в потенциальном голосе героя. Голос возвышается, но он увлекает за собой и собеседника, звуковая волна, расширяясь, поднимается вверх. Здесь нет завершенности интонации, это не «сплетенный» слог, требующий употребления периодов, по терминологии Аристотеля, а «нанизывающий», предполагающий высказывание, которое нельзя обозреть сразу. В такой речи авторский голос резонирует голосу Версилова.

Версилов рассказывает о том преображении, которое испытал сам в «косых лучах заходящего солнца» в Европе:

Ощущение счастья, мне еще неизвестного, прошло сквозь сердце мое, даже до боли, это была всечеловеческая любовь (XIII, 375).

Приняв идею Версилова о русском человеке как всеевропейце, Аркадий продолжает следовать словам Макара Долгорукого. Перед смертью Макар Иванович напутствует Аркадия:

Ты, милый, Церкви святой ревнуй, и аще позовет время и умри за нее... (XIII, 330).

Во время похорон Макара Долгорукого Подросток молится вместе со всеми в кладбищенской церкви, затем по просьбе матери уже дома читает Евангелие от Луки, где сквозной мыслью проходит идея нестяжания (XIII, 406- 
407). В черновике Достоевский ставит рядом идеи Версилова и Макара Ивановича в сознании Подростка:

После выздоровления: тоска по идеалу, идея ревности и мести и борьба с идеяли Макара и Версилова (XIII, 34).

Предостережением для Аркадия во время его внутренней борьбы с ревностью и жаждой мести становится судьба Версилова, Сокольского-младшего, Тришатова. Петр Тришатов в своей опере о Маргарите из «Фауста» утверждает идею спасения через покаяние и причащение (XIII, 353), в сцене из Диккенса он показывает преображение через возрождение в душе человека ребенка и образа Христа:

И вот раз закатывается солнце, и этот ребенок на паперти собора, вся облитая последними лучами, стоит и смотрит на закат с тихим задумчивым созерцанием в детской душе, удивленной душе, как будто перед какой-то загадкой, потому что и то, и другое, ведь как загадка - солнце, как мысль Божия, а собор, как мысль человеческая... (XIII, 353).

Очищение сердца Аркадия происходит благодаря пробуждению в нем образа Божьего. Его внутреннее изменение начинается с покаяния перед матерью. А затем сердцем овладевает сострадание к ближним: «убитый, отчаянный вид» Лизы «пронзил его сердце» (XIII, 391), «унизительная просьба» Версилова, обращенная к Ахмаковой, не выходить замуж «пронзала сердце» (XIII, 417), при взгляде на старого князя Сокольского и Анну Андреевну у него «сжалось сердце» (XIII, 426).

Второй круг испытаний Подростка заканчивается вновь жаждой хаоса и пожара у Ламберта (XIII, 418), но, оказавшись в полицейском участке, Аркадий овладевает собой:

Да, те мгновения были светом души моей. Оскорбленный надменным Бьорингом и завтра же надеясь быть оскорбленным тою великосветскою женщиной, я слишком знал, что могу им ужасно отомстить, но я решил, что не буду мстить (XIII, 438).

Очищение сердца он воспринимает как возвращение к себе:

Я перекрестился с любовью, лег на нары и заснул ясным, детским сном (XIII, 438).
Развязка событий происходит, видимо, 9 декабря в день иконы Божией Матери «Нечаянная радость». 13 декабря отмечается день Аркадия Новоторжского, одного из самых почитаемых владимиро-суздальских святых, возможно, небесного покровителя главного героя романа. Аркадий воспринимает спасение Ахмаковой и Версилова как чудо:

Но нас всех хранил Бог и уберег, когда все уже висело на ниточке (XIII, 441).

Топография Петербурга в третьей части «Подростка» напоминает «Преступление и наказание»: Аркадий снимает квартиру рядом с Вознесенским мостом, как и Соня Мармеладова, встречи с отцом происходят в трактире на канаве, как у Раскольникова и Мармеладова. Вместе с тем, принимая окончательное решение отдать документ, Аркадий приходит на квартиру к Татьяне Павловне, которая находится у Технологического института, недалеко от Московского проспекта Петербурга (XIII, 125).

Заканчиваются записки Аркадия тем, что он сближается с Татьяной Павловной и Ахмаковой, а Версилов возвращается в семью. В фринале говорится о Великом посте, о «новой жизни» и «новом пути» Подростка (XIII, 451). Путь Подростка - это движение от идеи Ротшильда, мечты об «уединении и могуществе» к противоположной идее нестяжания и соборности, носителем которой является Макар Долгорукий. Кроме того, Аркадий думает о продолжении образования. В черновиках к роману Достоевский ищет соединение идей Макара Долгорукого и Версилова:

Макар. Христа познай и Его проповедуй, а делами пример подавай, и будет незыблемо. Тем всему миру даже послужишь.

- Правда, - говорит Версилов, - Европа ждет от нас Христа. Она нам науку, а мы им Христа (в этом назначение России) (XVI, 141).

Достоевский в «Дневнике писателя» (1881) определил то, чем спасется русский народ, в отличие от европейского: верой во всесветное единение во имя Христово, в свободный духовный союз, основанный на детской любви народа к царю-отцу (XXVII, 18-22). Писатель верил, что народ русский хранит чистый образ Христов в своей православ- 
ной вере (XXIII, 130). В то же время он понимал важность петербургского (европейского) периода в истории России: западный человек склонен к рефлексии и самоанализу, а для самоопределения самопознание необходимо (XXIV, 182). В романе «Подросток» самосознание пробуждается в Аркадии Долгоруком, его можно отнести к типу «текущей действительности», которая устремлена в будущее (XIII, 455).

Сорья Андреевна - носительница соборного начала. В черновике к «Подростку» ее материнский образ несет благообразие:

Что живи в каком хочешь безобразии, но что, если существует еще материнская любовь, т. е. еще и благообразие (XVI, 365).

В образе Макара Ивановича Долгорукого намечается новый для европейской литературы герой пророческого типа, соборная личность, в которой уравновешиваются динамическое и статическое начала. Продолжением этого героя становятся Зосима и Алеша Карамазов. Преображение личности у Достоевского происходит на основе смирения и проявления свободы воли как следование воле Божией. 